\title{
NEW RECORDS AND DATA OF RHODOCOLLYBIA POPAYANICA (AGARICALES: OMPHALOTACEAE) FROM MEXICO
}

\author{
José Luis Villarruel-OrdaZ ${ }^{1,3}$ and Joaquín Cifuentes ${ }^{2}$ \\ ${ }^{1}$ Universidad del Mar, Instituto de Genética, campus Puerto Escondido, km 1.5 \\ road Puerto Escondido-Sola de Vega, 71980 Puerto Escondido, Oaxaca, México. \\ ${ }^{2}$ Universidad Nacional Autónoma de México, Facultad de Ciencias, Laboratorio de \\ Taxonomía y Biodiversidad de Hongos, Apdo. postal 70-181, \\ 04510 Coyoacán, México, D.F., México. \\ ${ }^{3}$ Author for correspondence: jlvo@zicatela.umar.mx
}

\begin{abstract}
Rhodocollybia popayanica is described as a new record for the Mexican mycobiota in the states of Chiapas, Hidalgo, México, Michoacán and Nayarit. The studied specimens are congruent with descriptions from Colombia and Costa Rica. With this record, Mexico becomes the northernmost limit for this neotropically distributed species.
\end{abstract}

Key words: Mexican mycobiota, neotropical, new records.

\section{RESUMEN}

Se describe a Rhodocollybia popayanica como nuevo registro de la micobiota mexicana en los estados de Chiapas, Hidalgo, México, Michoacán y Nayarit. Los especímenes estudiados concuerdan con las descripciones de Colombia y Costa Rica. Con este registro México llega a ser el límite septentrional de la distribución neotropical de esta especie.

Palabras clave: micobiota mexicana, nuevos registros, neotropical.

\section{INTRODUCTION}

The genus Rhodocollybia was segregated from Collybia s.l. based on the presence of cyanophilic and dextrinoid spores and pinkish spore print (Lennox, 
1979). Additionally, three other genera were segregated. Connopus, Dendrocollybia and Gymnopus are recognized based on macroscopic and microscopic characters as well as DNA data (Antonín et al., 1997; Halling, 1997; Hughes et al., 2001; 2010; Mata et al., 2004a; 2004b; Wilson and Desjardin, 2005). So far, on a worldwide basis more than 20 species are known to belong to Rhodocollybia (Kirk et al., 2008; Anonymous, 2014; Roskov et al., 2014). In Mexico only six species (including three varieties) have been reported for the genus, being Rhodocollybia butyracea (Bull.) Lennox and Rhodocollybia maculata (Alb. \& Schwein.) Singer the most frequently cited (Guzmán et al., 1992; VillarruelOrdaz et al., 1993).

As part of an ongoing review of collybioid agarics in Mexico, the authors found specimens fitting the diagnostic characters of Rhodocollybia popayanica (Halling) Halling, until now known only from Colombia and Costa Rica (Halling, 1989; Franco-Molano et al., 2000; 2010; Mata, 2002).

\section{MATERIALS AND METHODS}

All specimens were annotated in the field and examined in the laboratory following standard techniques of macromorphology and macrochemicals reactions described by Cifuentes et al. (1986). Basidiomata colors were matched with Kornerup and Wanscher (1978).

Basidiomata micromorphology was examined using light microscopy. Sections of different tissues were mounted either with 3-5\% aqueous $\mathrm{KOH}$ solution, lactic acid or Melzer's reagent; cotton blue or phloxine were used to stain cells when needed (Largent et al., 1977). The symbol "Q̄" represents the average of mean the length/width ratio of basidiospores. Most measurements and drawings were made using oil immersion objective at X 1250. A drawing tube was used to construct illustrations of microscopic features.

The following acronym appears below: FCME = Herbario, Facultad de Ciencias, Universidad Nacional Autónoma de México.

\section{RESULTS}

Rhodocollybia popayanica (Halling) Halling. 1997. Mycotaxon 63: 365. Figs. 1-6. 三 Collybia popayanica Halling. 1989. Mycologia 81: 872. 
Pileus 7-60 $\mathrm{mm}$ in diameter, first convex, then campanulate-umbonate, or sometimes plane-convex, with center sharply papillate to cuspidate, margin straight to uplifted, sometimes eroded when mature; surface glabrous to finely appressed-fibrillose, slightly striate by transparency, moist and hygrophanous; when young usually yellowish white (1-4A2) to pale yellow (3A3), when mature irregularly staining more pale yellow (3A4-4A3) or darker, at center becoming light brown (6D7) to brown (7E7); context thin, white to pale yellow (3-4A3); taste slightly bitter; smell pleasant.

Lamellae subattached to almost free, crowded, very narrow, whitish cream (2A1) to yellowish white (2-4A2); margin smooth, in age fimbriate to crenate. Stipe 22-105 mm long, 2-7 mm broad, cylindrical to compressed, twisted, attenuate toward apex and broader below; context fibrous-cartilaginous; surface moist to dry, glabrous or slightly fibrillose to scantly villous toward the base, yellowish white (2-4A2) or pale yellow (2-3A3), developing light yellow (4A4-5) stains toward the base with age. Basidiospores orange white (5A2) to grayish orange (5B3) in deposit, 6.3-7.5 X 3.5-4.2 mm ( $\overline{\mathrm{Q}}=1.8)$, amygdaliform in side view, ellipsoid in dorsal view, smooth, thin-walled, hyaline, many dextrinoid and cyanophilous. Basidia tetrasporic, 20-27 X 6-7 mm, clavate, sterigmata in some basidia measuring up to $8 \mathrm{~mm}$ in length. Pleurocystidia absent. Cheilocystidia $18-22$ X $6-7 \mathrm{~mm}$, clavate to cylindrical, diverticulate with short projections. Pileipellis a cutis, with entangled cylindrical hyphae, radially oriented. Clamp connections abundant and present in all tissues.

Habitat and distribution: Humicolous or on very rotten wood; in mixed PinusQuercus, and Mexican montane mesophytic forests, at 800-2090 meters above sea level. It occurs during the months of July to September and its edibility is unknown.

Macrochemical tests: Pileus and stipe context, as wells as gills turn pale yellow (2-3A3-4) with $\mathrm{KOH}(10 \%)$, pileus and stipe context turn grayish red (9B2-5) with Phenol (3\%), pileus and stipe context, as well as gills turn very pale orange (5A1-3) with formalin (40\%).

Studied material. MEXICO. CHIAPAS: Municipality of Ocozocuautla, educational park "Laguna Bélgica", km 18 road Ocozocuautla-Malpaso, Ocampo Genoveva 27 (FCME 10718); Gallegos Cupil 11 (FCME 10728). ESTADO DE MÉXICO: Municipality of Valle de Bravo, km 21 road San Francisco OxototilpaValle de Bravo, Pompa González 82 (FCME 2303, Photo Cifuentes 42-68); km 4 

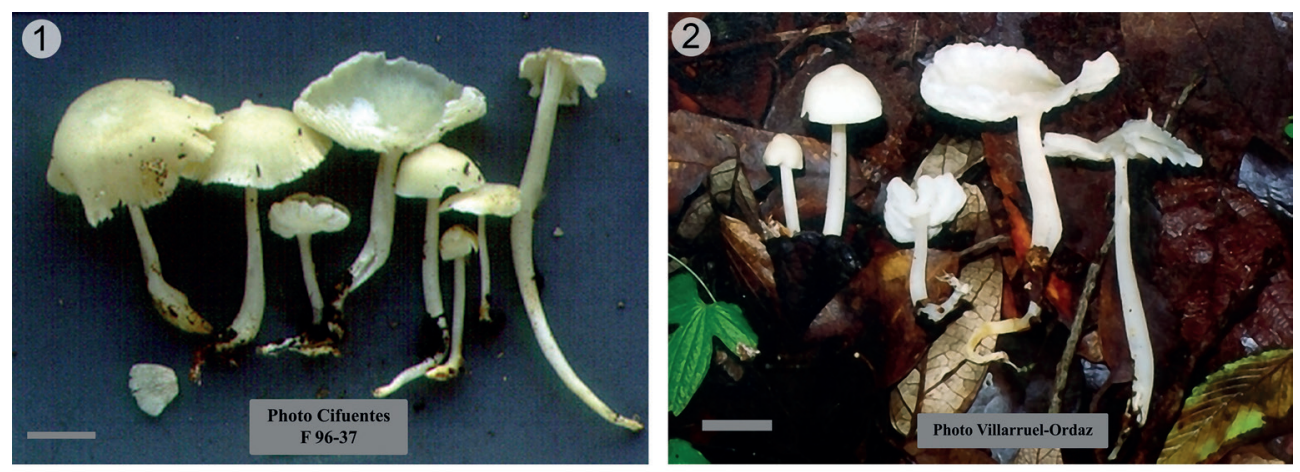

3

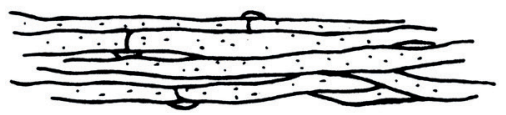

4

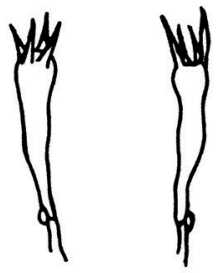

5

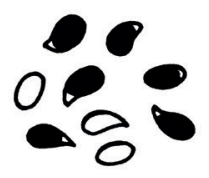

6

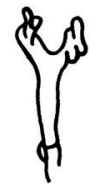

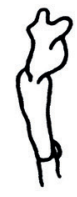

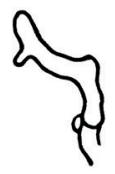

Figs. 1-6: Rhodocollybia popayanica. 1-2. basidiomata with cuspidate-umbonate pileus; 3. pileipellis hyphae (cross section); 4. basidia with sterigmata up to $8 \mu \mathrm{m}$ in length; 5 . basidiospores, many dextrinoid; 6 . cheilocystidia. Scale 1-2 $=2 \mathrm{~cm}, 3-6=10 \mu \mathrm{m}$.

circuit Manantiales-Avándaro, Hernández-Muñoz 32 (FCME 2205, Photo Cifuentes 42-68). HIDALGO: Municipality of Jacala, km 192 road Pachuca-Nuevo Laredo, Villarruel-Ordaz 902 (FCME 19634, Photo Villarruel-Ordaz 2002-2). MICHOACAN: Municipality of Charo, National park "Insurgente José Ma. Morelos", Audelo Valona 19-august-1983 (FCME 11471). NAYARIT: Municipality of Tepic, km 4.5 deviation to "El Cuarenteño" hill San Juan, Villarruel-Ordaz 131 (FCME 1985); km 6 deviation to "El Cuarenteño" hill San Juan, Villarruel-Ordaz 432 (FCME 18371, Photo Cifuentes 96-37); km 11 deviation to "El Cuarenteño" hill San Juan, Cifuentes 2781 (FCME 2600, Photo Cifuentes 39-92); "La Capillita” hill San Juan, VillarruelOrdaz 106 (FCME 3913, Photo Hernández-Muñoz 1-12); "La Capillita" hill San Juan, Villarruel-Ordaz 123 (FCME 4343, Photo Cifuentes 46-83); "La Noria" hill San Juan, Villarruel-Ordaz 110 (FCME 4063). 


\section{DISCUSSION}

Rhodocollybia popayanica is easily distinguished by its campanulate to planoconvex pileus, which is clearly cuspidate to papillate at center. At first, basidiomata are almost white or very pale yellow but tend to develop yellow or brown stains when older. Previous descriptions (Halling, 1989; Franco-Molano et al., 2000) have reported a more yellow to brown coloration (as brown as $6 \mathrm{C} 4$ and at center could be in age as reddish as 7-8A3), as well as longer stipe dimensions ( 80 to $200 \mathrm{~mm}$ ), but Mata (2002) found paler basidiomata with shorter stipe just like the Mexican specimens. Mata (2002) related such variations to different developmental stages and we concur with his opinion.

Rhodocollybia popayanica is similar to the $R$. maculata complex because of the yellowish basidiomata (Halling, 1989), but we regard its consistency as cartilaginous rather than fibrous, just like in $R$. butyracea. In addition, $R$. maculata has globose spores while $R$. popayanica are ellipsoid.

Rhodocollybia popayanica is now recorded from central, southwestern and southern Mexico (Chiapas, Estado de México, Hidalgo, Michoacán and Nayarit). It seems to be widely distributed in the Neotropics with Colombia and Mexico respectively as its southern and northern limits so far.

\section{ACKNOWLEDGMENTS}

Field trips and laboratory research were funded in part by projects PAPIIT IN-208391, IN-206901 and IN-207311 from the Universidad Nacional Autónoma de México.

\section{LITERATURE CITED}

Antonín, V., R. E. Halling and M. E. Noordeloos. 1997. Generic concepts within the groups of Marasmius and Collybia sensu lato. Mycotaxon 63: 359-368.

Anonymous. 2014. Index fungorum. CABI Bioscience, CBS and Landcare Research. www. indexfungorum.org. Viewed on september of 2014.

Cifuentes, J., M. Villegas and L. Pérez-Ramírez. 1986. Hongos. In: Lot, A. and F. Chiang (eds.). Manual de herbario. Consejo Nacional de la Flora de México, A.C., México, D.F., México. pp. 55-64.

Franco-Molano, A. E., R. Aldana-Gómez and R. Halling. 2000. Setas de Colombia (Agaricales, Boletales y otros hongos). Guía de campo. COLCIENCIAS. Universidad de Antioquía. Medellín, Colombia. 156 pp. 
Franco-Molano, A. E., A. Corrales and A. M. Vasco-Palacios. 2010. Macrohongos de Colombia II. Listado de especies de los órdenes Agaricales, Boletales, Cantharellales y Russulales (Agaricomycetes, Basidiomycota). Actual Biol. 32(92): 89-113.

Guzmán, G., V. M. Bandala and L. Montoya. 1992. Noteworthy species of Collybia from Mexico and a discussion of the known Mexican species. Mycotaxon 44: 391-407.

Halling, R. E. 1989. Notes on Collybia III. Three neotropical species of subg. Rhodocollybia. Mycologia 81: 870-875.

Halling, R. E. 1997. A revision of Collybia s.l. in the northeastern United States and adjacent Canada. http://www.nybg.org/bsci/res/col/colintro.html. Viewed on august of 2014.

Hughes, K. W., D. A. Mather and R. H. Petersen. 2010. A new genus to accommodate Gymnopus acervatus (Agaricales). Mycologia 102: 1463-1478.

Hughes, K. W., R. H. Petersen, J. E. Johnson, J. M. Monclavo, R. Vilgalys, S. A. Redhead, T. Thomas and L. McGhee. 2001. Infrageneric phylogeny of Collybia s.s. based on sequences of ribosomal ITS and LSU regions. Mycol. Res. 105: 164-172.

Kirk, P. M., P. F. Cannon, D. W. Minter and J. A. Stalpers. 2008. Dictionary of the Fungi. 10a. ed. CAB International. Wallingford, Great Britain. $771 \mathrm{pp}$.

Kornerup, A. and J. H. Wanscher. 1978. Methuen Handbook of Colour. 3rd ed. Eyre Methuen. London, Great Britain. 224 pp.

Largent, D. L., D. Johnson and R. Watling. 1977. How to identify mushrooms to genus III: Microscopic features. Mad River Press. Eureka, USA. 148 pp.

Lennox, J. W. 1979. Collybioid genera in the Pacific Northwest. Mycotaxon 9: 117-231.

Mata, J. L. 2002. Taxonomy and systematics of Lentinula, Gymnopus and Rhodocollybia (Agaricales, Fungi), with emphasis on oak forests of southern Costa Rica. Ph.D. dissertation. University of Tennessee. Knoxville, USA. 263 pp.

Mata, J. L., R. E. Halling and R. H. Petersen. 2004a. New species and mating system reports in Gymnopus (Agaricales) from Costa Rica. Fungal Divers. 16: 113-129.

Mata, J. L., R. E. Halling, K. H. Hughes and R. H. Petersen. 2004b. Rhodocollybia (Agaricales) in neotropical montane forests. Mycol. Prog. 3: 337-351.

Roskov, Y., T. Kunze, T. Orrell, L. Abucay, L. Paglinawan, A. Culham, N. Bailly, P. M. Kirk, T. Bourgoin, G. Baillargeon, W. Decock, A. De Wever and V. Didžiulis (eds.). 2014. Species 2000 \& ITIS Catalogue of Life-Annual Checklist 2014. www.catalogueoflife. org/annual-checklist/2014. Viewed on september 2014.

Villarruel-Ordaz, J. L., L. Pérez-Ramírez and J. Cifuentes. 1993. Nuevos registros del género Collybia (Tricholomataceae) y descripción de especies poco estudiadas en México. Rev. Mex. Mic. 9: 139-164.

Wilson, A. W. and D. E. Desjardin. 2005. Phylogenetic relationships in the gymnopoid and marasmioid fungi (Basidiomycota, euagarics clade). Mycologia 97: 667-679. 